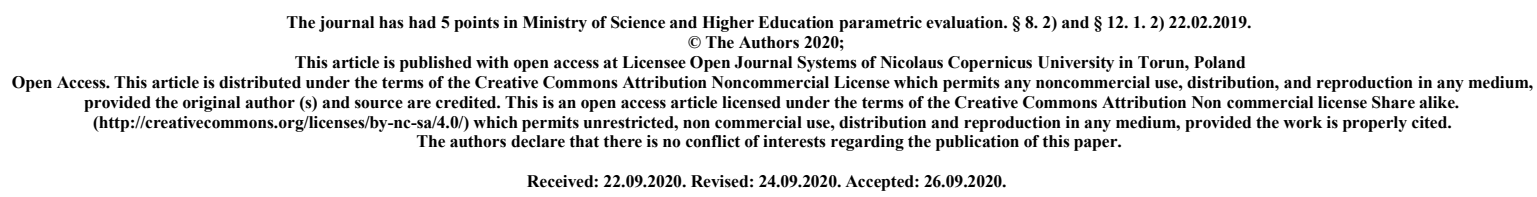

\title{
The bitter side of high fructose corn syrup (HFCS) - the global obesity pandemic
}

\author{
Siedlecka Dagna ${ }^{1}$, Micał Wojciech ${ }^{2}$, Krzewicka-Romaniuk Ewa ${ }^{1}$, Romaniuk Artur $^{3}$ \\ ${ }^{1}$. Department of Pathophysiology, Medical University of Lublin, Poland \\ 2. 1 st Department of Medical Radiology, Medical University of Lublin, Poland \\ 3. Praktyka Lekarza Rodzinnego „Familia” ul. Niepodległości 29, 21-040 Świdnik, Poland
}

Key words: high fructose corn syrup; fructose; HFCS; syrup; sweetener; obesity

\begin{abstract}
Sweet taste accompanies our lives since childhood. Sugar is commonly used in industrial production. Increased consumption of simple sugars has been observed since many years. Sugars come in different forms and one of them - glucose-fructose is on scientists aim because if it's impact on health. Fructose has unique metabolic features, that could be harmful for human organism. Excessive consumption of this substance contributes to obesity pandemic, development of diabetes mellitus and cardiovascular disease. Obesity affects in particular children and teenagers.[1] High consumption of fructose disturb sense of hunger and satiety.
\end{abstract}




\section{Fructose}

Fructose (chemical formula $\mathrm{C} 6 \mathrm{H} 12 \mathrm{O} 6$ ) is a monosaccharide similar to glucose. It is natural compound of honey, fruit and flower nectar. GLUT-5 transporter has high affinity to fructose and it takes part in passive absorption of it in intestine - process independent from insulin. This transporter is absent in brain or pancreas B cells - it means that fructose transport to those tissues is limited. Fructose doesn't cause satiety. It doesn't increase insulin release, at the same time it increase insulin tissue sensitivity. Fructose decrease postprandial leptin release that is responsible for long term energetic homeostasis regulation. It increases ghrelin (hunger hormone) secretion. Lower leptin and insulin concentration and elevated ghrelin level contributes to excessive eating and obesity.[2,3]

\section{High fructose corn syrup (HFCS)}

High fructose corn syrup (HFCS) and sucrose are main sources of fructose in processed foods. HFCS is a sweetener made from corn starch using process of enzymatic isomerization of glucose to fructose. It's widely used because of low price. HFCS is used as a sweetener in juices, sodas and foods like yoghurts, jams, bread and spices. Daily calorie intake increased during last few years, and according to recent studies $50 \%$ comes from sweet drinks consumption..[4] Over the years HFCS use in food industry increased. It has been proven that obesity, metabolic disorders and cardiovascular diseases are related to HFCS consumption. Furthermore HFCS rich products are considered as 'empty calories' - those supply mainly calories but no other nutrients (vitamins, protein, fiber, minerals).[5-8]

Fructose concentration in the most common HFCS forms used in food industry are $42 \%$ or 55\%:[9]

- HFCS-42: contains 42\% of fructose (appeared in 1967) - it's used mostly in foods like jams, pastry, diary and beer

- HFCS-55: contains 55\% of fructose (introduced in 1977) - used mainly in soft drinks (carbonated and not carbonated) and juices

\section{Obesity}

Obesity is one of the leading preventable causes of death worldwide. It is a medical condition in which excess body fat has accumulated to an extent that it may have a negative effect on health. It is correlated with various diseases: type 2 diabetes, cardiovascular diseases, obstructive sleep apnea.

To assess overweight and obesity we can use a measurement body mass index (BMI). BMI is obtained by dividing a person's weight by the square of the person's height [BMI = person's weight $(\mathrm{kg})$ : square of the person's height $\left.\left(\mathrm{m}^{2}\right)\right]$. High BMI may be a marker of risk 
for diseases. People are generally considered obese when their body mass index is over 30 $\mathrm{kg} / \mathrm{m}^{2}$.

\begin{tabular}{|l|l|}
\hline BMI (kg/m2) & Classification \\
\hline $17,0-18,49$ & underweight \\
\hline $18,5-24,9$ & normal weight \\
\hline $25-29,9$ & overweight \\
\hline $30,0-34,99$ & class I obesity \\
\hline $35,0-39,99$ & class II obesity \\
\hline$\geq 40,0$ & class III obesity \\
\hline
\end{tabular}

Tab. 1 Adult body weight classification based on body mass index, BMI [10] (some East Asian countries use lower values)

Ludwig et al. showed that consumption of sugar-sweetened beverages (SSB) is associated with obesity in children. In a prospective cohort study they measured the association between the intake of SSB and change in BMI, in a group of 548 children for 19 months. The risk of obesity [odds ratio (OR) 1.60; 95\% confidence interval (CI), 1.14-2.24; $\mathrm{p}=0.02]$ was significantly increased in children with increased SSB intake, after adjustment for demographic, dietary and lifestyle variables.[11] Kosova et al. made a cross-sectional analysis of National Health and Nutrition Examination Survey (NHANES) during 1999-2004, data collection by the National Center for Health Statistics. They evaluated the relationship between sugar-sweetened beverage intake and cardio metabolic markers in a group of 4880 children at age of 3-11. The association between SSB intake and BMI percentile was not significant $(\mathrm{P}=0.07)$.[12]

Ambrosini et al. examined an association between SSB intake and obesity measured by change of BMI. They followed a group of 1433 adolescent offspring from Western Australian Pregnancy Cohort study. Girls $(n=600)$ who were moved into the top tertile of SSB consumption had significantly greater changes in BMI. No significant association was observed in boys $(n=706)$. [13] Bremer et al. examined the association between SSB intake and BMI in groups of adolescents at age of 12-19. Based on information derived from NHANES questionnaire, subjects were classified as: non-Hispanic black, non-Hispanic white and Mexican American. There was a significant association between SSB intake and BMI among Mexican Americans and non-Hispanic whites $(\mathrm{p}<0.05)$, after adjustment for total energy intake, age and physical activity.[14]

Bermudez and Gao also found a significant correlation between SSB intake and incidence of obesity, after adjustment for age, total energy intake and physical activity. This study included 947 US adults at age of 20-39 years old.[15] Higher intake of SSB was significantly associated with a increased incidence of obesity in Dhingra et al. prospective cohort study that included 4277 US adults.[16]

\section{Summary}

High sugar diet is responsible for many health problems. Epidemic studies showed that high fructose diet is related to cardiovascular and metabolic diseases. Despite a lot of research proved negative influence of HFCS on human health its use is not restricted. HFCS has GRAS status (generally recognized as safe) - it means that it's considered as safe food ingredient. Nutritional education is important to decrease HFCS negative effects on health. 


\section{References:}

1. Forshee RA, Anderson PA, Storey ML. Sugar-sweetened beverages and body mass index in children and adolescents: a meta-analysis. Am J Clin Nutr. 2008 Jun;87(6):1662-71.

2. Stanhope KL, Medici V, Bremer AA, et al. A dose-response study of consuming highfructose corn syrup-sweetened beverages on lipid/lipoprotein risk factors for cardiovascular disease in young adults. Am J Clin Nutr. 2015 Jun;101(6):1144-54.

3. Schwartz MW, Baskin DG, Kaiyala KJ, Woods SC. Model for the regulation of energy balance and adiposity by the central nervous system. Am J Clin Nutr. 1999 Apr;69(4):584-96.

4. Popkin BM, Armstrong LE, Bray GM, et al. A new proposed guidance system for beverage consumption in the United States. Am J Clin Nutr. 2006 Mar;83(3):529-42.

5. Malik VS, Popkin BM, Bray GA, et al. Sugar-sweetened beverages, obesity, type 2 diabetes mellitus, and cardiovascular disease risk. Circulation. 2010 Mar 23;121(11):1356-64.

6. de Koning L, Malik VS, Kellogg MD, et al. Sweetened beverage consumption, incident coronary heart disease, and biomarkers of risk in men. Circulation. 2012 Apr 10;125(14):1735-41, S1.

7. Trumbo PR, Rivers CR. Systematic review of the evidence for an association between sugar-sweetened beverage consumption and risk of obesity. Nutr Rev. 2014 Sep;72(9):566-74.

8. Johnson RJ, Segal MS, Sautin Y, et al. Potential role of sugar (fructose) in the epidemic of hypertension, obesity and the metabolic syndrome, diabetes, kidney disease, and cardiovascular disease. Am J Clin Nutr. 2007 Oct;86(4):899-906.

9. Sadowska J, Rygielska M. Technological and health aspects of using high fructose syrup in food production. Available from: http://www.pttz.org/zyw/wyd/czas/2014,\%203(94)/02_Sadowska.pdf

10. Gajewski P, Augustynowicz-Kopeć E, Wydawnictwo Medycyna Praktyczna. Interna Szczeklika: podręcznik chorób wewnętrznych 2013. Kraków: Medycyna Praktyczna; 2013.

11. Ludwig DS, Peterson KE, Gortmaker SL. Relation between consumption of sugarsweetened drinks and childhood obesity: a prospective, observational analysis. Lancet Lond Engl. 2001 Feb 17;357(9255):505-8.

12. Kosova EC, Auinger P, Bremer AA. The relationships between sugar-sweetened beverage intake and cardiometabolic markers in young children. J Acad Nutr Diet. 2013 Feb;113(2):219-27.

13. Ambrosini GL, Oddy WH, Huang RC, et al. Prospective associations between sugarsweetened beverage intakes and cardiometabolic risk factors in adolescents. Am J Clin Nutr. 2013 Aug;98(2):327-34.

14. Bremer AA, Byrd RS, Auinger P. Differences in male and female adolescents from various racial groups in the relationship between insulin resistance-associated parameters with sugar-sweetened beverage intake and physical activity levels. Clin Pediatr (Phila). 2010 Dec;49(12):1134-42. 
15. Bermudez OI, Gao X. Greater consumption of sweetened beverages and added sugars is associated with obesity among US young adults. Ann Nutr Metab. 2010;57(3-4):211-8.

16. Dhingra R, Sullivan L, Jacques PF, et al. Soft drink consumption and risk of developing cardiometabolic risk factors and the metabolic syndrome in middle-aged adults in the community. Circulation. 2007 Jul 31;116(5):480-8. 